\title{
First record of pilotfish Naucrates ductor (Linnaeus 1758), Carangidae, in the syrian marine waters (Levantine Basin)
}

\author{
Nour Ali-Basha ${ }^{*}$, Adib Saad ${ }^{1}$, Nader Hamwi ${ }^{2}$ and Abdullah Tufahha ${ }^{1}$
}

\begin{abstract}
This paper presents the first record of Naucrates ductor ( Linnaeus 1758) from Syrian waters. One specimen (300 mm TL, $294.29 \mathrm{~g} \mathrm{TW}$ ) was caught by purse-seine nets at about $60 \mathrm{~m}$ depth from Lattakia coast, on 25 September 2020. This record represents the first of this cosmopolitan species that entered the Syrian waters (Eastern Mediterranean).
\end{abstract}

Keywords: Naucrates ductor, Pilotfish, Carangidae, Syrian waters, Levantine Basin

\section{Introduction}

The Carangidae family includes 147 species worldwide belonging to 30 genera (Nelson et al. 2016), from this high species diversity, 7 genera include 12 species are found in Syrian waters, from which one Aleps djedaba (Forsskal 1775) is an immigrant species from the Red sea (Saad 2005; Ali 2018).

Pilotfish, Naucrates ductor (Linnaeus 1758) is a pelagic oceanic species almost cosmopolitan in tropical and subtropical seas, distributes in Eastern Atlantic: British Isles, the Azores and Madeira, Norway and Bay of Biscay to Namibia, including the Mediterranean and the Canaries, also it is common throughout the Indian Ocean (SmithVaniz 1986; Froese and Pauly 2018), and has occasionally been caught in the Black Sea (Bauchot 1987).

Naucrates ductor has a semi-obligate commensalisms with large cartilaginous or bony fishes, turtles, marine mammals, ships and driftwood; juveniles often associated with seaweeds and jellyfishes; larvae are epipelagic in ocean water. The link of pilotfish with floating objects is still not clear, though several hypotheses (protection,

\footnotetext{
* Correspondence: dr.nour.alibasha@gmail.com

${ }^{1}$ Marine Sciences Laboratory, Faculty of Agriculture, Tishreen University,

Lattakia, Syria

Full list of author information is available at the end of the article
}

visual stimulus and help in predation) are suggested (Pipitone et al. 2000).

Pilotfish feeds on host's food scraps and possibly as a cleaner that consumes ectoparasites, also small fishes and invertebrates (Golani et al. 2006; Carpenter and Angelis 2016; Froese and Pauly 2018). It is mostly caught as by-catch of the seasonal (August through December) dolphin fish fishery in the Mediterranean using purseseine nets around fish aggregation devices (FADs) (Reñones et al. 1999; Pipitone et al. 2000) and is of minor commercial value, however, this is not considered a major threat to its global population. It is therefore assessed as least concern (Smith-Vaniz et al. 2015). The species has been reported in Izmir Bay (Aegean Sea) by Akyol (2019), Libya (Southern Mediterranean sea) by Elbaraasi et al. (2019), in Egypt by Akel and Karachle (2017), and in the Adriatic sea (Glamuzina et al. 2017), also has been known from eastern Mediterranean (BenTuvia 1971), but up to date there is no published evidence of the occurrence of this species in the Syrian marine waters (Saad 2005; Ali 2018). So, we present here the first confirmed occurrence of Naucrates ductor from Syrian waters.

(c) The Author(s). 2021 Open Access This article is licensed under a Creative Commons Attribution 4.0 International License, which permits use, sharing, adaptation, distribution and reproduction in any medium or format, as long as you give appropriate credit to the original author(s) and the source, provide a link to the Creative Commons licence, and indicate if changes were made. The images or other third party material in this article are included in the article's Creative Commons licence, unless indicated otherwise in a credit line to the material. If material is not included in the article's Creative Commons licence and your intended use is not permitted by statutory regulation or exceeds the permitted use, you will need to obtain permission directly from the copyright holder. To view a copy of this licence, visit http://creativecommons.org/licenses/by/4.0/. 


\section{Materials and Methods}

One specimen of Naucrates ductor was caught on 25 September 2020, during artisanal fishing operation, using purse-seine nets at a depth of $60 \mathrm{~m}$, from south of Lattakia city (Fig. 1), where the seawater surface temperature was $28.4{ }^{\circ} \mathrm{C}$. The specimen was measured to the nearest $(\mathrm{mm})$, weighted to the nearest $(\mathrm{g})$ and morphometric measurements with percentages of standard length (SL). The specimen was preserved in $10 \%$ buffered formalin and deposited in the Ichthyological collection of the Marine Sciences laboratory, Faculty of Agriculture, Tishreen University (Reference No: MSL 21/2020). (Fig. 2)

\section{Results}

Naucrates ductor specimen has a total length (TL) $300 \mathrm{~mm}$, with total weight (TW) 294.29 g. Morphometric and Meristic data of the specimen is summarized in (Table 1). The specimen of this species presents the following characteristics: body elongate, shallow, and barely compressed, with nearly equal upper and lower profiles, but head profile tapering sharply above anterior half of upper jaw to produce a nearly blunt snout. Upper jaw very narrow posteriorly and extending to about anterior margin of eye. Teeth minute, in a band in upper and lower jaws (Fig. 3, a).Gill rakers on first arch 6 upper, 18 lower and 24 total. Dorsal fin with IV spines, followed by I spine and 27 soft rays; anal fin with II spines separated from rest of fin followed by I spine and 16 soft

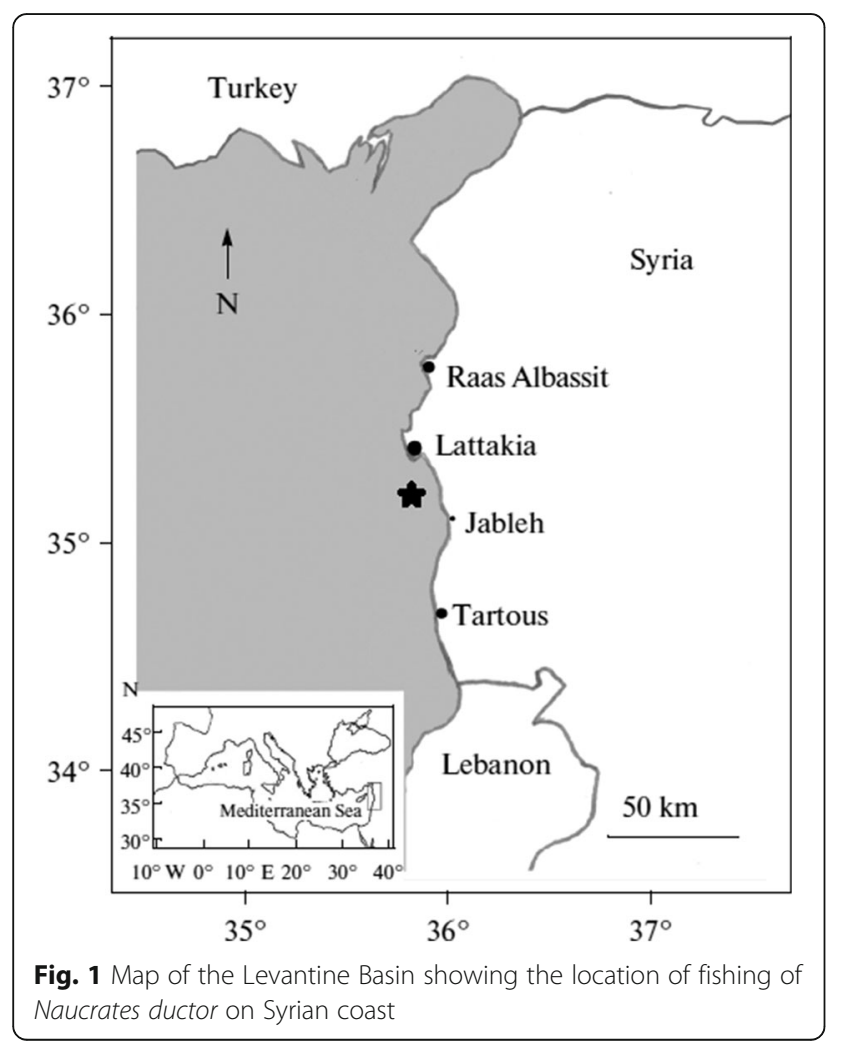

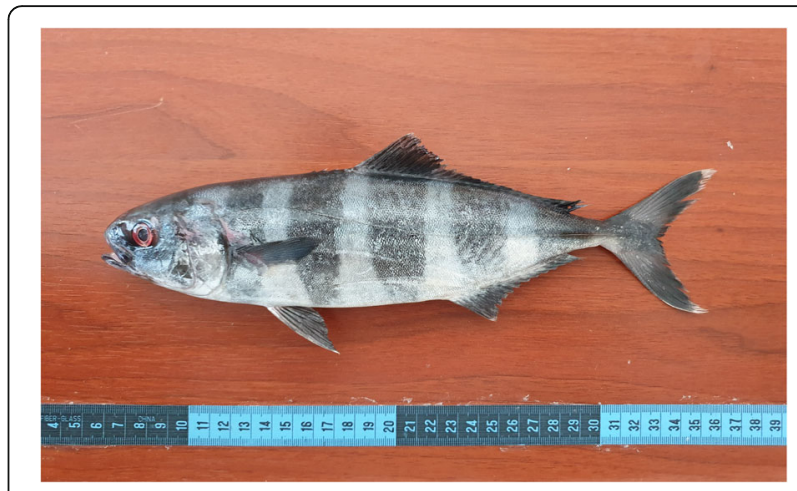

Fig. 2 Naucrates ductor with $300 \mathrm{~mm} \mathrm{TL}$, caught off south of Lattakia city

rays. Scales very small and ctenoid; no scutes. Caudal peduncle with a well-developed lateral, fleshy keel on each side and dorsal and ventral peduncle grooves (Fig. 3, b). Colour: head dark, 5 dark broad body bands and a similar band at end of caudal peduncle; rest of body light; white tips prominent on upper and lower caudal

Table 1 Morphometric measurements in $\mathrm{mm}$ and as a percentage of standard length (\%SL), counts and weight in grams recorded in the specimen of Naucrates ductor caught off the Syrian coast

\begin{tabular}{lll}
\hline Morphometric measurements & $\mathbf{m m}$ & SL\% \\
\hline Total length (TL) & 300 & $114.95 \%$ \\
Fork length (FL) & 267 & $102.29 \%$ \\
Standard length (SL) & 261 & $100 \%$ \\
Body depth (BD) & 65 & $24.90 \%$ \\
Head length (HL) & 61 & $23.37 \%$ \\
Eye diameter (ED) & 11 & $4.21 \%$ \\
Pre-orbital length (Pol) & 16 & $6.13 \%$ \\
Post-orbital length & 34 & $13 \%$ \\
Pre-dorsal length (Pdl) & 118 & $45.21 \%$ \\
Dorsal fin base length (D.B.L) & 104 & $39.85 \%$ \\
Pre-pectoral length (Ppl) & 66 & $25.29 \%$ \\
Pectoral length & 37 & $14.18 \%$ \\
Pre-anal length (Pal) & 163 & $62.45 \%$ \\
Anal fin base length (A.B.L) & 58 & $22.22 \%$ \\
Peduncle depth (PD) & 15 & $5.75 \%$ \\
Caudal peduncle length & 45 & $17.24 \%$ \\
Counts
\end{tabular}

\section{Counts}

$\begin{array}{ll}\text { Dorsal fin rays } & \mathrm{IV}+\mathrm{I}+27 \\ \text { Anal fin rays } & \mathrm{I}+\mathrm{I}+16 \\ \text { Pelvic fin rays } & \mathrm{I}+5 \\ \text { Pectoral fin rays } & 20 \\ \text { Total weight (TW) g } & 294.29\end{array}$



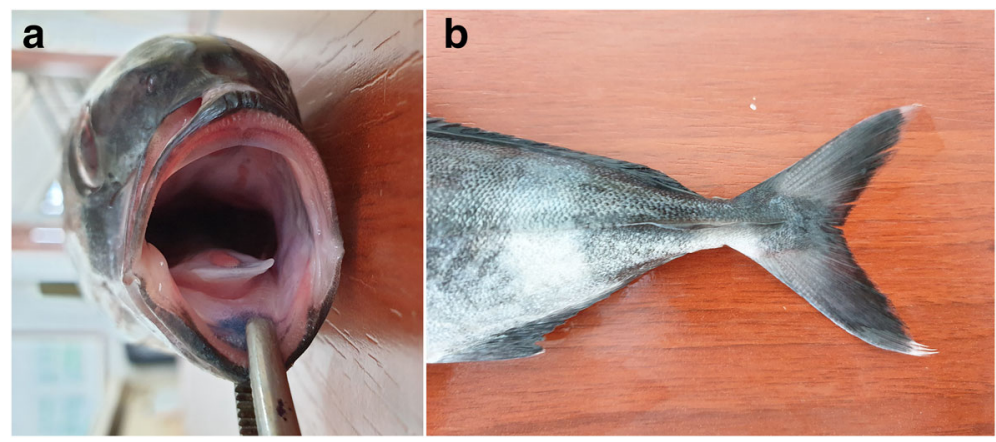

Fig. 3 a Upper and lower jaws, b Caudal peduncle

fin lobes and smaller white tips on second dorsal and anal fin lobes; most of fins dusky to dark.

\section{Discussion}

All measurements, counts, and colour patterns determined the morphological analyses in previous other records of this species in north- eastern Atlantic and the Mediterranean (Smith-Vaniz 1986), the Eastern Mediterranean (Golani et al. 2006), and the Central Eastern Atlantic (Carpenter and Angelis 2016). The Total length of our specimen $(300 \mathrm{~mm})$ is larger than those specimens obtained by Akyol (2019) $(275 \mathrm{~mm})$ from Izmir Bay and by Glamuzina et al. (2017) $(28.71 \mathrm{~cm})$ from Adriatic sea. According to Mediterranean data the fisheries include only specimens not larger than $29-30 \mathrm{~cm}$ (6 months age), and this is smaller than the reported maximum size for the area (63 cm fork length according to Smith-Vaniz 1986). Probably around the age of six months pilotfish abandon the association with floating objects and adopt a more erratic behaviour, that make them unavailable to common sampling methods and to fishermen (Pipitone et al. 2000). A similar behavior is displayed by the greater amberjack Seriola dumerili, which is closely associated with flotsam up to a size of about $10 \mathrm{~cm}$, after which it leaves the upper layers of water and changes feeding habits (Pipitone and Andaloro 1995). Since the Pilotfish has a semi-obligate commensalisms with other organisms, so this species is always migratory and linked to the movement of these organisms whose movement is affected by the constant flow of near-surface waters that enter through Gibraltar strait from the Atlantic into the Mediterranean due to strong evaporation in the Eastern Basin of the Mediterranean Sea, and this could explain the occurrence of the Naucrates ductor in our waters at this time of year. Obviously, this species does not have a negative impact and is not competing with the indigenous species as it is mobile and mainly feeds on organisms food scraps that associated with it also small fish and invertebrates so it is a positive evidence of biodiversity in the Syrian marine waters, as these organisms found in our coasts a safe habitat or safe passages for their transport in the Mediterranean.

\section{Conclusions}

The presently reported capture of pilotfish Naucrates ductor (Linnaeus, 1758) from the Syrian coast would indicate that the species might be venturing and expanding further in the Mediterranean to reach new areas. This specimen is the first documented case for this species in the Syrian waters after it was first observed in several areas of Mediterranean. Consequently, this sighting should be considered as the northernmost record made along the eastern Mediterranean coasts to date.

\section{Acknowledgements}

We express our thanks to Mr. Mohammad Fares for bringing the specimen of Naucrates ductor to our attention. We are grateful to the editor and an anonymous referee for their valuable comments on the first draft of the manuscript.

Authors' contributions

$\mathrm{AS}, \mathrm{NH}, \mathrm{AT}$ and NA-B examined specimen and drafted the manuscript. All authors gave the final approval for publication.

\section{Funding}

Not applicable.

\section{Availability of data and materials}

The specimen is available at Marine Laboratory- Tishreen university- LattakiaSyria.

Ethics approval and consent to participate

No ethical approval or consent to participate was required.

\section{Consent for publication}

Not applicable.

\section{Competing interests}

The authors declare that they have no competing interests.

\section{Author details}

${ }^{1}$ Marine Sciences Laboratory, Faculty of Agriculture, Tishreen University, Lattakia, Syria. ${ }^{2}$ Ichthyology Laboratory, Faculty of Veterinary medicine, Hama University, Hama, Syria. 
Received: 8 October 2020 Accepted: 10 February 2021

Published online: 23 February 2021

\section{References}

Akel Kh, Karachle PK. The marine ichthyofaunal of Egypt. Egyptian Journal of Aquatic Biology Fisheries. 2017;21(3):81-116.

Akyol O. Occurrence of Pilotfish Naucrates ductor (Carangidae) in Izmir Bay (Aegean Sea). Turkish Journal of Maritime Marine Sciences. 2019;5(1):17-20,

Ali M. An updated checklist of the marine fishes from Syria with emphasis on alien species. Mediterranean Marine Science. 2018;19(2):388-93.

Bauchot ML. Carangidae. In: W. Fischer, M. Schneider and ML Bauchot, editors, Vertebres. Fishes FAO d'identification des especes pour les besoins de la peche (Revision 1). FAO, Rome; 1987. p.\&nbsp;1009-1030.

Ben-Tuvia A. Revised list of the Mediterranean fishes of Israel. Israel Journal of Zoology. 1971;20:1-39.

Carpenter KE, De Angelis N. The living marine resources of the Eastern Central Atlantic. Vol.\&nbsp;4: Bony fishes part 2 (Perciformes to Tetradontiformes) and Sea turtles. Rome: FAO Species Identification Guide for Fishery Purposes; FAO; 2016. pp.\&nbsp;2343-3124.

Elbaraasi H, Elabar B, Elaabidi S, Bashir A, Elsilini O, Shakman E, Azzurro E. Updated checklist of bony fishes along the Libyan coast (southern Mediterranean Sea). Mediterranean Marine Science. 2019;20(1):90-105.

Glamuzina B, Bartulović V, Glamuzina L, Dobroslavić T. Records of New Fish Species in the River Neretva Estuary: Potential Threat to Coastal Adriatic Nursery. Naše more. 2017;64(3):86-9.

Golani D, Öztürk B, Başusta N. The Fishes of the Eastern Mediterranean. Turkish Marine Research Foundation, Istanbul; 2006; Publication No. 24: 259 pp.

Nelson J, Grande TC, Wilson MVH. Fishes of the world. Fifth edition. Wiley, United States of America; 2016; 707 pp.

Pipitone C, Andaloro F. Food and feeding habits of juvenile greater amberjack Seriola dumerili (Osteichthyes, Carangidae) in inshore waters of the central Mediterranean Sea. Cybium. 1995;19(3):305-10.

Pipitone C, Campagnuolo S, Andaloro F, Potoschi A. Diet of pilotfish, Naucrates ductor, associated with FADs in Sicilian waters (central Mediterranean). Cybium. 2000;24(4):415-8.

Reñones O, Morales-Nin B, Deudero S. Population size structure, age and growth of Naucrates ductor in the small scale FADs fishery off Mallorca Island (western Mediterranean). Scientia Marina. 1999;63(3-4):355-66.

Saad A. Check-list of bony fish collected from the coast of Syria. Turkish J Fish Aquatic Sci. 2005;5:99-106.

Smith-Vaniz WF. Carangidae. In: (Eds. Whitehead PJP, Bauchot ML, Hureau JC, Nielsen J, Tortonese E) Fishes of the Northeastern Atlantic and the Mediterranean. Vol.\&nbsp;ill (pp.\&nbsp;815-844). Paris, France, UNESCO; 1986; 1473 pp.

Smith-Vaniz WF, Brown J, Pina Amargos F, Williams JT, Curtis M. Naucrates ductor. The IUCN Red List of Threatened Species. 2015: e.T190452A115322218. https://doi.org/10.2305/IUCN.UK.2015-4.RLTS.T190452A16643992.en.

Froese R, Pauly D, editors. FishBase. World Wide Web electronic publication. Retrieved from http://www.fishbase.org, version06/2018. Accessed 14 November 2018.

\section{Publisher's Note}

Springer Nature remains neutral with regard to jurisdictional claims in published maps and institutional affiliations. 